\title{
NOWY ATEIZM: CZY RZECZYWIŚCIE NOWY? ANALIZA ARGUMENTÓW I WYZWAŃ DLA WSPÓŁCZESNEJ TEOLOGIl
}

Choć określenie „nowy ateizm” (NA), jak często to bywa w przypadku nowych terminów, bardzo szybko zwróciło na siebie uwagę, zwłaszcza środków przekazu, to jednak z wielu stron rozległo się zasadne pytanie: na ile wysuwane propozycje można rzeczywiście określić jako „nowe”. Trzeba przyznać, że renesans kwestii istnienia Boga w przestrzeni intelektualnej przełomu XX i XXI wieku wzbudził spore zdziwienie: wydawało się, że jest to temat, który został już dokładnie zbadany i zamknięty, dlatego nie ma prawa odżyć tak, jak choćby w średniowieczu, gdy zagadnienie dróg dojścia do Boga ogniskowało uwagę największych intelektualistów epoki ${ }^{1}$. Powszechny indyferentyzm religijny, właściwy

* Ks. Piotr Roszak - dr hab. teologii, adiunkt Zakładu Teologii Fundamentalnej i Religiologii na Wydziale Teologicznym UMK w Toruniu; profesor stowarzyszony Uniwersytetu Nawarry w Pampelunie; redaktor serii "Scholastica Thoruniensia".

* Ks. Francisco Conesa - dr teologii i dr filozofii, wykładowca filozofii języka oraz teologii fundamentalnej w Seminario Diocesano-Teologado (Alicante) oraz profesor stowarzyszony Uniwersytetu Navarry w Pampelunie.

${ }^{1}$ Choć expressis verbis temat ateizmu nie pojawia się u św. Tomasza, to jednak zagadnienie 'niewiary' i dróg dochodzenia do intelektualnego przyświadczenia (assensus) 
dla secular age, by przywołać znamienny tytuł książki Ch. Taylora², jak się wydawało, uśpił i osłabił zainteresowanie religijnością, która będąc traktowana $\mathrm{w}$ ponowczesnym paradygmacie $\mathrm{w}$ dużej mierze jako złudzenie i mało istotne „konfesyjne” zagadnienie, skazana była zdaniem wielu na stopniowe zanikanie. Pojawienie się nowego ateizmu stanowi w tym sensie swoistą nowość: wyraża przekonanie, że religia jednak nie zniknęła wedle planów ateistów oświeceniowych. Doprowadziło to tym samym do rozbudzienia starych filozoficzno-teologicznych debat, które pojawiły się $w$ mediach i dyskusjach akademickich. Niczym zamknięte rozdziały powieści, w której nie ma prawa wydarzyć się już nic ciekawego, bo wszystko zostało już w narracji wyjaśnione, a dzieło zmierza do rozwiązania akcji i finału, a które to rozdziały nagle okazują się "otwarte". Pod koniec XX wieku utrwaliło się społeczne przekonanie, że po upadku żelaznej kurtyny i komunizmu w Europie środkowo-wschodniej, upadł także jego programowy ateizm, a przynajmniej znajduje się w ostatnich podrygach ${ }^{3}$. Tymczasem $\mathrm{w}$ ostatnich latach pojawiła się znaczna liczba publikacji, które wracają do starych - jeszcze oświeceniowych argumentów przeciw istnieniu Boga ${ }^{4}$. Warto prześledzić zasadnicze linie argumentacji przedstawicieli nowego ateizmu, aby przekonać się, czy są one bardziej kontynuacją dawnej (oświeceniowej) tradycji ateistycznej czy też mamy do czynienia - jak zdaje się sugerować nazwa - z czymś nowym. Będąc fenomenem niezwykle medialnym, neoateizm stał się przez to również wyzwaniem dla refleksji teologicznej: doprowadził do powstania specyficznej formy apologetyki, która zasługuje na głębszą analizę

właściwego dla wiary stanowił ważny komponent jego myśli - por. S. Brock, Can Atheism be Rational? A Reading of Thomas Aquinas, "Acta Philosophica”, 2 (2002), s. 215-238.

${ }^{2}$ Ch. Taylor, A Secular Age, Cambridge-London 2007.

${ }^{3}$ Por. T. Eagleton, Faith, Reason and Revolution: Reflections on the God Debate, New Haven 2009.

${ }^{4}$ Por. F. Conesa, El nuevo ateismo: exposicion y analisis, "Scripta Theologica" 3 (2011), s. 547-592. W prezentacji poglądów nowego ateizmu opieram się na przedstawionych przez hiszpańskiego teologa analizach twierdzeń reprezentatów tej wersji ateizmu.

${ }^{5}$ Przyczynkiem do budowy tej formy apologetyki jest książka Davida Betleya Harta, Atheist Delusions: the Christian Revolution and Its Fashionable Enemies, New Haven 2009. Na temat sposobów polemiki z nowym ateizmem, por. J. Wojtysiak, Jak rozmawiać z nowym (i nie nowym) ateizmem, w: Nauki przyrodnicze a nowy ateizm, Lublin 2012, s. 169-102. Autor dokonuje ciekawej analizy argumentów antyteistycznych Dawnkinsa (zwł. słynnego porównania „z Boeinga 747”). Por. także: F.A. Murphy, New Atheism: are we amused?, "Pro Ecclesia" XIX 4 (2010), s. 453-459, w którym autorka zwraca uwagę na 


\section{NOWY ATEIZM JAKO ATEIZM POSTMODERNISTYCZNY: PRÓBA OPISU}

Ateizm postmodernistyczny zasadniczo postrzega się jako ateizm "cichy", praktyczny, nie podejmujący bezpośredniej polemiki z teizmem. To ateizm pewny, że religia skazana jest na wymarcie $w$ toku dziejów i wystarczy wykazać się odrobiną cierpliwości. W tym świetle łatwiej zrozumieć rozróżnienie - wprowadzone przez J. Haughta - na ateizm "twardy", który cechuje myślicieli świadomych, że ich ateizm prowadzi do nihilizmu (np. „mistrzów podejrzeń”, którzy wyczuwają tragiczność swego losu) od ateizmu "słabego", który nie rozpacza nad utratą czegoś ważnego, a nawet wręcz przeciwnie proklamuje radosć z bycia ateistą ${ }^{6}$. Nowy ateizm wpisuje się $\mathrm{w}$ ten drugi nurt, wracający do argumentów podnoszonych w oświeceniu przeciw istnieniu Boga, choć trzeba podkreślić jego znamienną dwutorowość, którą można dostrzec przy wnikliwej analizie poglądów prezentowanych przez neoateistów. Do przedstawicieli nowego ateizmu zwykło się zaliczać przede wszystkich Richarda Dawkinsa (ur. 1941), Christophera Hitchensa (1949-2011), Daniela Denetta (ur. 1942) oraz Sama Harrisa (ur. 1967). Autorzy ci pochodzą z kręgów kultury i myśli anglosaskiej i różnią się od dwóch innych, których często przedstawia się w kontekscie neoateizmu: Andre Comte-Sponville i Michela Onfraya, reprezentujących wariant kontynentalny.

Termin new atheism został ukuty przez Garry'ego Wolfa i zamieszczony w listopadowym numerze czasopisma „Wired” (14/2006) w artykule zatytułowanym „Kościół niewierzących”. Już wówczas Wolf zwracał uwagę na charakterystyczną cechę nowego ateizmu, którą jest wrogość wobec wszelkiej religii (choć wielu z nich skupia się przede wszystkim na islamie): nie wystarcza im stwierdzenie fałszywości religii, ale dążą do przekonania, że jest ona również czymś złym. W tym celu posługuja się najnowszymi narzędziami medialnymi, korzystają z usług marketingowych, aby wygrać dialektyczne starcia telewizyjne (charakterystyczne dla świata anglosaskiego, tzw. "God debates") $)^{7}$. Już pobieżna lektura samych tytułów ich książek (np. „Traktat ateologiczny”, „Bóg urojony”,

apologetyczne reakcje w łonie ruchu „Radykalnej Ortodoksji”, zwłaszcza w kontekście przenoszenia przez NA ewolucjonistycznego modelu na inne nauki humanistyczne.

${ }^{6}$ J. Haught, God and the new atheism: a Critical Response do Dawkins, Harris and Hitchens, Westminister John Konx Press, Louisville 2008, s. 55nn.

7 D. Martinez, Los nuevos ateos, "Nuestro tiempo" 641 (2007), s. 99-107. 
„Bóg nie jest wielki. Jak religia wszystko zatruwa”) przekonuje, że posługują się nazwami nośnymi marketingowo, nastawiając się czytelnie na wzbudzenie polemiki i szybkie zapamiętanie ich naczelnych argumentów. Są niezwykle radykalni w stawianiu problemów, preferując obraz czarno-biały, bez żadnych odcieni. Dlatego ich poglądy nie są próbą nawiązania filozoficznego dialogu na temat istnienia Boga, ale przekazem już zdobytej przez nich „prawdy absolutnej”. Z tego powodu przez niektórych krytyków są określani jako nowi fundamentaliści ${ }^{8}$ czy nawet porównywani do radykalnych kaznodziejów, którzy straszą ogniem piekielnym albo nową apokalipsą tych, którzy nie odrzucają religii jako czegoś złego' ${ }^{9}$ Mają mentalność bardziej „misjonarzy” niż teologów - nastawieni są bowiem nie tyle na poszukiwanie prawdy, ile na jej rozpowszechnianie (i dlatego bardziej stawiają na poszukiwanie skutecznej strategii) ${ }^{10}$.

Znamienną cechą „nowego ateizmu” jest jego programowa negacja Boga dokonywana w imię nauki, choć w dużej mierze - co najbardziej charakterystyczne i paradoksalne w tym ateizmie - opiera się na uczuciach, zwłaszcza wyrażanych wobec fenomenu religii. Przez „naukę” rozumieją model ewolucjonistyczny, który ich zdaniem czyni hipotezę Boga całkowicie niepotrzebną, a wręcz szkodliwą ${ }^{11}$. To jednak nie temat istnienia bądź nieistnienia Boga polaryzuje ich uwagę, ich dyskurs kieruje się bowiem $\mathrm{w}$ pierwszym rzędzie przeciw religiom, a dopiero $\mathrm{w}$ drugiej instancji podejmują się - jak zobaczymy poniżej - przedstawienia i analizy argumentów przeciw istnieniu Boga. W gruncie rzeczy mamy więc do czynienia $\mathrm{z}$ ateizmem "przeciwreligijnym”. W przekonaniu przedstawicieli "nowego ateizmu” religia to najgorsza rzecz, jaka mogła się przydarzyć ludzkości. Nie chodzi tylko o to, że religia jest fałszywa, ale jest źródłem zła i nieszczęścia dla ludzkości, o czym przekonują tak podkreślane przez nich „czarne karty” historii religijnej. Na celowniku totalnej krytyki „nowego ateizmu” znajduje się obok islamu również

8 A. McGrath, J.C. McGrath, Bóg nie jest urojeniem, Kraków 2007, s. 15.

${ }^{9}$ Jest to obserwacja, jakiej dokonuje słynny ateista, który pod koniec swego życia odrzucił jednak ateizm (choć Dawkins uważa, że to z powodu podeszłego wieku) - widzi w nich owych głosicieli, którzy nawołują do „nawrócenia od religii”, nie wiedzą co to dwuznaczności czy substelności - każdy, kto choćby wyrazi intelektualną sympatię dla religijności jest dla nich potencjalnym zdrajcą. Por. A. Flew, There is a God: How the World's Most Notorious Atheist Change His Mind, New York 2007, s. 16n.

10 Por. P. Gutowski, Czym jest nowy ateizm, s. 23.

${ }^{11}$ Por. P. Roszak, Wiarygodność i tożsamość. Teologia wiary św. Tomasza z Akwinu a wspótczesność, Kraków 2013. 
chrześcijaństwo, które jest ich zdaniem „religią dla kretynów”, niegodną inteligencji człowieka.

Retoryka nowych ateistów, choć odwołuje się do światopoglądu naukowego, to jednak bardziej niż rozwiązanie intelektualnej aporii interesuje ją osiągnięcie jasnego celu społeczno-politycznego: wyrugowanie religii z życia publicznego. Czytelne jest tu zwłaszcza postępowanie R. Dawnkinsa, który czerpiąc wzorce $\mathrm{z}$ ruchów feministycznych stara się doprowadzić przede wszystkim do zmiany języka i modeli myślenia o ateizmie: chce wykorzenić negatywne skojarzenia ze słowem "ateista" i przenieść je na "religijny”, „wierzący”. Temu ma służyć tzw. out compaign, projekt zachęcający do publicznego wyrażania swoich ateistycznych poglądów i niedopuszczenia do sytuacji, w której staje się tematem tabu ${ }^{12}$. Uzasadnione wydaje się więc twierdzenie Francisco Conesy, że neoateizm jest bardziej ruchem społecznym niż postawą intelektualną. Hiszpański teolog z Alicante w swoim obszernym i systematycznym studium wskazuje na kilka, jego zdaniem, kluczowych uwarunkowań społecznych, które doprowadziły do narodzin nowego ateizmu ${ }^{13}$. Wybrzmiewają one w lekturze ksiażek i artykułów obu autorów, które są wprost przez nich identyfikowane i sprowadzają się do czterech zasadniczych motywów. Pierwszy to konsekwencje ataków terrorystycznych z 11 września 2001 r., które powinny ich zdaniem doprowadzić do przewartościowania postrzegania religii, będącej odpowiedzialną za zamachy w Stanach Zjednoczonych. W jednym z artykułów w The Guardians Dawkins pisał, że aż do tych wrześniowych wydarzeń myślał o religii jak o tkliwym pocieszeniu, ale okazało się, że tolerowanie tego przesądu ma tragiczne konsekwencje. Wiara religijna nie jest niegroźnym głupstwem, wywołującym uśmiech politowania, jak wielu ateistów jego zdaniem do tej pory przypuszczało, lecz zjawiskiem niebezpiecznym, bo doprowadzającym do nienawiści i zabijania innych ludzi w imię racji religijnych. W kulturze swego czasu Dawnkins widzi „dziwny respekt” wobec religii, który sprawił, że nie stała się ona przedmiotem krytyki. Wydarzenia z 11 września były jasnym sygnałem, że należy to zmienić.

Fenomen nowego ateizmu rozwija się przede wszystkim w środowisku anglosaskim i odwołuje się do dwóch innych czynników społecznych, właściwych zwłaszcza dla sytuacji w USA. Chodzi z jednej strony o zjawisko proliferacji sekt w Stanach Zjednocznych, ale także - a może

\footnotetext{
12 Por. P. Gutowski, Czym jest nowy ateizm?, s. 11.

${ }^{13}$ Por. F. Conesa, El nuevo ateismo, s. 560.
} 
przede wszystkim - o negowanie przez pewne grupy chrześcijan teorii ewolucji, co doprowadziło do napięcia czy konfrontacji między osobami utrzymującymi literalną intepretację opisu z Księgi Rodzaju i ewolucjonistami, którzy mocno krytykują zarówno zwolenników takiej lektury Genesis jak i zwolenników teorii inteligentnego projektu ${ }^{14}$. Warto jeszcze wspomnieć o ostatnim z uwarunkowań społecznych, tym razem szczególnie aktualnym $\mathrm{w}$ kontekście kontynentalnym. Wiąże się to ze zmianą dyskursu europejskiej lewicy, która w wyniku upadku muru berlińskiego i fiaska projektu komunistycznego w Europie środkowo-wschodniej, a także oddziaływania pontyfikatu Jana Pawła II (i odczuwanej przez to hegemonii chrześcijańskiej kultury) została zmuszona do zmiany strategii działania. Akcent tego dyskursu przeniósł się z kwestii ekonomicznych na projekt budowania nowych wartości współżycia społecznego, co związane było z przyjęciem ideologii laicyzmu ${ }^{15}$.

\section{DWA OBLICZA "NOWEGO ATEIZMU": GENEZA I PRZEDSTAWICIELE}

W prezentacji poglądów nowego ateizmu warto krótko scharakteryzować głównych przedstawicieli. Znamienne jest to, że najbardziej znani neoateiści zajmują się różnymi dziedzinami, niektórzy są filozofami, ale pozostali $\mathrm{w}$ swej pracy naukowej związani są z naukami ścisłymi, matematyką czy dziennikarstwem. Autorzy dostrzegają dwie tendencje, które określają oblicze nowego ateizmu: z jednej strony silne podkreślanie, że odkrycia naukowe przekreślają sens istnienia religii oraz z drugiej strony powrót do pewnych francuskich ideałów oświeceniowych.

\subsection{NURT SCJENTYSTYCZNY: "CZTEREJ JEŹDZCY" NOWEGO ATEIZMU}

Wśród przedstawicieli tego nurtu dominuje przekonanie, że jedynie nauki doświadczalne mogą dostarczyć całkowitego wyjaśnienia świata i tym, co realnie istnieje, jest jedynie natura: nie istnieje zatem ani Bóg,

${ }^{14}$ Por. S. Collado, Análisis del diseno inteligente, „Scripta Theologica” 39 (2009), s. $573-605$.

15 Szerzej o przemianach w łonie europejskiej lewicy (zwłaszcza „późnej lewicy") - por. B. Kuźniarz, Good bye, Mr Postmodernism. Teorie społeczne późnej lewicy, Toruń 2012, s. 17-30. 
ani dusza, ani życie po śmierci. Natura nie jest stworzona przez Boga, lecz reprodukuje się sama i jest możliwa do wyjaśnienia na bazie jedynie przyczyn naturalnych. Dotyczy to także ludzkich fenomenów (takich jak inteligencja), które są w pełni wyjaśnialne dzięki przyjęciu perspektywy ewolucji, tak jak ją głosił Darwin. W gruncie rzeczy jednak rozwija teorię ewolucji, aplikując ją do wyjaśnienia wszystkich zjawisk. Tym samym przestają być ewolucjonistami i stają się filozofami ewolucjonizmu. Ewolucja jest dla niego doktryną metafizyczną o rzeczywistości, którą widzi jako naczelną charakterystykę całej rzeczywistości.

Jedną z ikon tej wersji ateizmu scjentystycznego jest Richard Dawkins, który zajmuje katedrę „publicznego rozumienia nauki” (Public Understandig of Science), stworzą dla niego w 1995 roku w Oksfordzie. Jest z wykształcenia zoologiem, który pracował na uniwersytecie w Berkeley. Agresywny ton jego ateizmu nie pojawia się nagle, lecz można dostrzec stopniową radykalizację poglądów począwszy od pierwszej książki Samolubny gen (1976) ${ }^{16}$. To właśnie w tej publikacji wprowadza ideę "memów” (neologizmy oznaczające replikatory kulturowe, podobne do genów), a religia jest jednym ze szkodliwych memów, a więc w gruncie rzeczy „szkodliwym wirusem umysłu” ${ }^{\prime 17}$. W kolejnych książkach nabiera kształtu scjentystyczne ukierukowanie nowego ateizmu: Ślepy zegarmistrz $(1986)^{18}$ to obrona darwinizmu i atak na ideę Inteligentnego Projektu, z kolei Rzeka Eden to rozważania dotyczące pojawienia się życia na ziemi, natomiast Kapelan diabła to zebranie najważniejszych argumentów przeciw religii rozumianej jako szkodliwa dla osobowości. Swoistym podsumowaniem i najważniejszą obroną ateizmu była ksiażka Bóg urojony $(2006)^{19}$, w której Dawkins przyjmuje naturalistyczne wyjaśnienie religii na bazie ewolucjonizmu darwińskiego oraz jasno formułuje swoje dwa zasadnicze zarzuty wobec religii: jest irracjonalna i niemoralna. Religia, wbrew twierdzeniom Kanta, nie ma już funkcji moralnej, bo praktyka zasad jej funkcjonowania zdradza, że są one głęboko niemoralne. W duchu programowego naturalizmu wyjaśnia fenomen religijności Daniel Dennett, filozof nauki, zajmujący się w swoich badaniach kwestią sztucznej inteligencji, intencjonalności i świadomości. Denetta interesuje zagadnienie, w jaki sposób struktura neuronalna pomaga wyjaśnić fenomen religii i tego, że ukształtowała się

\footnotetext{
${ }_{16}$ R. Dawkins, Samolubny gen, Prószyński, Warszawa 1996.

17 F. Conesa, El nuevo ateismo, s. 557.

18 R. Dawkins, Ślepy zegarmistrz, Warszawa 1997.

19 R. Dawkins, Bóg urojony, Warszawa 2007.
} 
w człowieku falszywa wiara w nadprzyrodzoność. Jest to prawdopodobnie najbardziej otwarty na dialog $\mathrm{z}$ wierzącymi przedstawiciel nowego ateizmu. Jego przeciwieństwem, ze wzlędu choćby na język, który opiera się na satyrze i wyśmiewaniu, jest brytyjski dziennikarz Christopher Hitchens. Główne jego myśli streszcza już sam tytuł jego programowej ksiażki: Bóg nie jest dobry. Operując uproszczeniami i generalizując, wskazuje na religię jako generującą złe postępowanie. $\mathrm{Z}$ tego faktu wynika kilka konsekwencji, że religia jest ludzkim wymysłem, że moralność i etyka są niewyprowadzalne $\mathrm{z}$ wiary oraz że religia jest nie tyle amoralna, ile głęboko niemoralna. Równie agresywny ton przybierają publikacje najmłodszego z czterech jeźdzców nowego ateizmu, Sama Harrisa. Już studiując filozofię w Stanford, napisał książkę Koniec wiary, której główną tezą jest przekonanie, że religia jest irracjonalna, a przez to prowadzi do terroru i nietolerancji. Znając zagrożenia, które niesie z sobą religia, stawia on na wzmocnienie marginalizacji religii w życiu społecznym.

\subsection{NURT OŚWIECENIOWY}

Charakterystyczną cechą tej postaci neoateizmu jest czytelne nawiązanie do materializmu oświeceniowego, ale również do postulatów F. Nietzschego, uznawanego za pierwszego, który stworzył alternatywę dla chrześcijaństwa. Bardzo zbliżoną postawę do anglosaskich neoateistów przyjmuje Michel Onfray, którego sztandarowym dziełem jest Traktat ateologiczny $(2005)^{20}$. Jego 'ateologia' to nie czysta negacja czy „znoszenie" teologii, lecz droga paralelna do niej i skupiona na filozoficznym „demontażu” Boga. Składa się ona z trzech metodologicznych kroków: najpierw ukazania, że wszystkie monoteizmy cechują się nienawiścią do inteligencji, życia, ciała i kobiety. W drugim kroku pojawia się ukazanie tradycji judeochrześcijańskiej jako niebezpiecznej fikcji, pewnej neurozy. Kiedy dokonana zostanie w pełni ta "dekonstrukcja” religijności, będzie możliwe zbudowanie etyki prawdziwie postchrześcijańskiej, w której naczelne miejsce zajmie hedonizm. Warto zwrócić uwagę na szczególną genezę ateizmu Onfraya: jego ateizm nie jest punktem „dojścia”, wynikiem ścisłego rozumowania, ale punktem „wyjścia”, który wynika z przyjętych a priori założeń materialistycznych. To właśnie jego aprioryczny materializm ustawia go $\mathrm{w}$ takiej naturalistycznej perspektywie.

${ }^{20}$ M.Onfray, Traktat ateologiczny. Fizyka metafizyki, Warszawa 2009. 
Drugim z autorów wpisujących się w oświeceniowe tradycje ateistyczne jest Andre Comte-Sponville ${ }^{21}$. Wyróżnikiem jego propozycji - przemyślanej i systematycznej - jest naszkicowanie głównych linii „duchowości ateistycznej”, o której pisał w ksiażce Dusza ateizmu. Wprowadzenie do duchowości bez Boga. U Comte-Sponville'a ateizm jest wiara, że Bóg nie istnieje: choć nie ma dostatecznych dowodów na to, że Bóg nie istnieje, utrzymuje Comte-Sponville, to jednak są pewne racje, aby wierzyć, że Go nie ma. Nie oznacza to jednak uwięzienia w immanecji i materializmie, lecz otwarcie ludzkiego bytu na ducha. Tym samym $\mathrm{w}$ przeciwieństwie do anglosaskiego wariantu nowego ateizmu, nie opowiada się za walką z religią, ale z oskurantyzmem, fanatyzmem czy integryzmem ${ }^{22}$.

\section{W CO WIERZA „NOWl ATEIŚCl"? MAPOWANIE NEOATEIZMU}

Systematyczne opracowanie tez nowego ateizmu miesza "stare" i "nowe": oznacza bowiem powrót do tradycyjnych argumentów antyteistycznych, ale przedstawianych w nowej perspektywie. Oparte na analizach Conesy poniższe zestawienie przekonań nowego ateizmu i uzupełnione o obserwacje innych autorów jest przede wszystkim próbą ukazania swoistych kierunków myślenia neoateizmu oraz głównych ognisk dyskusji prowadzonych obecnie $\mathrm{z}$ jego przedstawicielami. $\mathrm{W}$ rezultacie otrzymuje swoistą mapę poglądów nowego ateizmu, która ma pokazać, jak rozkładają się akcenty i zasadniczne linie argumentacji.

\subsection{TOTALNOSĆ WIEDZY NAUKOWEJ: W STRONE NOWEGO PARADYGMATU RACJONALNOŚCl}

Najważniejszym z argumentów nowego ateizmu, a przy tym stanowiącym swoiste "ramy”, w których mieści się sposób myślenia neoateistów, to przekonanie o kompatybliności metody właściwej dla nauk ścisłych dla wszelkiego rodzaju poznania. Przesłanką ich myślenia jest naturalizm, który wyraża się w postawie scjentyzmu, zarówno w jego

${ }^{21}$ A. Comte-Sponville, A-t-on encore besoin d'une religion?, Ivry-sur-Seine 2003.

${ }^{22}$ Por. J. Tellez, Etre moderne. Introduction á la pensé d'André Comte-Sponville, Meaux 2008. 
wersji „mocnej” (gdy doświadczenie empiryczne jest traktowane jako jedyne źródło wiedzy o świecie) czy słabej (gdy uznaje się je za najlepsze źródło wiedzy o świecie). Jak zauważa Conesa, oznacza to w gruncie rzeczy redukcję epistemologiczną świata do tego, co naturalne, gdyż według neoateistów poza tym, co naturalne nic nie istnieje ${ }^{23}$. W świecie nowego ateizmu dopuszczalne są tylko te wierzenia, które mają adekwatne uzasadnienie naukowe (postawa określana jako 'ewidencjalizm'). Wiara $\mathrm{w}$ tym paradygmacie staje się przesądem nie opartym na żadnych przesłankach czy dowodach. Tym samym Dawkins i Hitchens wracają do oświeceniowej idei wiary jako przejściowej postawy, charakterystycznej dla pewnego etapu - dziecinnego - rozwoju świata, który powinien zostać przezwyciężony. Dziwnie jedynie brzmią w tym kontekście słowa Woltera, który to właśnie ateizm traktował jako „dziecinną chorobę ludzkiego umysłu".

Dialektyczne napięcie między nauką a wiarą sprowadza tę ostatnią do synonimu irracjonalności, zamknięcia na świat i swoistej ślepoty. Dlatego religia jest ostatecznie wrogiem cywilizacji i sprzymierzeńcem barbarzyństwa. Wierzący to ktoś, zdaniem neoateistów, kto nienawidzi inteligencji i instrumentalizuje wiedzę, a przez to postawa religijna jest umniejszeniem i szkodą dla osobowości, ciasnotą intelektualną, która nie pozwala narodzić się nowym ideom. To podkreślanie nieprzezwyciężalnego konfliktu i opozycji między nauką a wiarą jest szczególnym wyróżnikiem nowych ateistów: próby pogodzenia ich ze sobą kończą się fiaskiem ze względu na irracjonalny charakter wiary, która ich zdaniem zachęca do „śpiewania psalmów”, a nie do myślenia. Neoateiści posługują się stereotypami funkcjonującymi w pewnych sektorach życia społecznego, w których „wierzę, więc przestaję myśleć” miałoby być etykietką ludzi wierzących, co jednak jest oczywistym uproszczeniem i rozminięciem się $\mathrm{z}$ tym, czym wiara jest w swej istocie. Pozytywistyczna wiara w postęp cechująca Hitchensa nie tylko sprawia, że postrzega on relację między wiarą a naukę w kategoriach „nieuniknionej wrogości”, lecz także pozwala żywić nadzieję, żę teleskop i mikroskop, dwa symbole postępu dla Hitchensa, ostatecznie zepchną religię w przestrzeń niegodną uwagi.

Trzeba zwrócić uwagę na sposób, w jaki nowy ateizm postrzega wiarę: zapewne trudno byłoby się rozpoznać wielu wierzącym $\mathrm{w}$ tym portrecie "ludzi wiary”, który wymalowali nowi ateiści. Wiara nie ry-

${ }^{23}$ Por. F. Conesa, El nuevo ateísmo, s. 561. 
walizuje $\mathrm{z}$ nauką $\mathrm{w}$ kwestii wyjaśniania świata, bo nie jest namiastką wiedzy ani pseudonauką, która dyspensuje wierzącego od pytań i poszukiwania prawdy. Dawnikns traktuje wiarę jako „wyciszacz” myślenia racjonalnego, Harris widzi ją przez pryzmat braku oczywistości i jako narzucanie pewnych przekonań. Dlatego w ich oczach wiara jest zawsze zła, ponieważ nie liczy się z argumentami, a tym samym - jak powie Dennett - przeraża swoją irracjonalną pewnością, że zna odpowiedzi na wszystkie pytania ${ }^{24}$. Nic więc dziwnego, że ostecznie postrzegają wiarę jako „szkodliwą głupotę”.

Jest to jednak charakterystyka wiary mocno chybiona, zważywszy choćby na definicję wiary takich klasyków teologicznej refleksji, jak św. Augustyn czy św. Tomasz z Akwinu, dla których wiara to dynamizm rozumu i woli, skoro wierzyć oznacza "przekonanym będąc, dalej rozumować" (cum assensione cogitare) ${ }^{25}$. Oznacza to, że wiara nie jest statycznym utrzymywaniem poglądów, ale ciągłym dążeniem do prawdy już uchwyconej i ciągle nienasycającej człowieka. Zwłaszcza Tomasz z Akwinu poświęcał wiele uwagi, aby pokazać wiarę nie jako ideologię, lecz jako poznanie oparte na osiągniętej pewności. Z drugiej strony sama nauka spoczywa na pewnym akcie wiary w swoje założenia i dlatego jest fenomenem egzystencjalnym nieobcym człowiekowi.

\subsection{RELIGIA JAKO ŹRÓDłO PRZEMOCY}

W przeciwieństwie do poprzednich epok, które stawiały hasło emancypacji nauki z wpływów religii, neoateiści chcą czegoś więcej: wyrugowania religii z przestrzeni życia społecznego i zdyskredytowania jakiejkolwiek formy życia religijnego. Przebija w tym postulacie nie tyle konfrontacja teoretyczna czy światopoglądowa, ile realizacja praktyczna eliminacji religii z życia publicznego. Uwidacznia się $\mathrm{w}$ ten sposób jedna $z$ głównych cech nowego ateizmu, jaką jest ich skupienie nie tyle na „problemie Boga", co na walce z religią.

Przedstawiane argumenty na rzecz wizji świata bez religii mają swoją metodologię. U jej źródeł znajduje się przeświadczenie, że religia jest tożsama z fanatyzmami (od czego znamiennie wyłamuje się A. Com-

${ }^{24}$ D. Dennett, Romper el hechizo. La religión como fenómeno natural, Madrid Buenos Aires 2007, s. 75.

${ }^{25}$ S. Th., II-II, q.1. 
te-Sponville), absurdalnością wyznawanych poglądów i dlatego to ona jest odpowiedzialna za szereg aktów terroru, które spotkały świat w XX wieku. Każdy z wierzących postrzegany jest jako potencjalny terrorysta ${ }^{26}$, i dlatego pokój na świecie będzie możliwy dopiero z chwilą zniknięcia ostatniej religii. Co znaczące, tak ostry zarzut wobec wszystkich religii na świecie nie jest poparty przez nowych ateistów jasnym ukazaniem koniecznościowego związku między religią a przemocą. Wspominają jedynie o wojnach "religijnych" i ironicznie wskazują na zabijanie drugiego człowieka pomimo przykazania miłości. Z pasją rozważają - z ogromną jednak dawką ignorancji - te historie opisywane w świętych księgach religii (zwłaszcza judaizmu i chrześcijaństwa), w których Bóg jawi się jako niemoralny „monstruum”, będący zawsze mściwym, zazdrosnym, karzącym, usprawiedliwiającym morderstwa i niewolnictwo ${ }^{27}$.

Trudno nie zauważyć szeregu słabych stron tego rodzaju rozumowania nowego ateizmu. W mniemaniu jego zwolenników wszystkie religie mają wspólny mianownik, są po prostu „religiami” i nie ma między nimi różnicy, co jest absolutnie fałszywe, bo przecież już pobieżna analiza różnych religii istniejących na świecie jasno ukazuje, że są między nimi realne różnice, religie nie są sobie równe. Jednowymiarowy obraz religii jest jej spłaszczeniem: nie dostrzega się dobra, które czynią w świecie ludzie religijni. Zasadniczy jednak problem nowego ateizmu, gdy próbuje opisywać fenomen religii ma charakter hermeneutyczny: opcja na rzecz znaczenia literalnego tekstów religijnych wypacza obraz, który analizują i sprawia, że mamy do czynienia z lekturą fundamentalistyczną tym razem ateistyczną. Nie potrafią czytać tekstów wielkich tradycji religijnych ludzkości, osadzać ich w kontekście epoki i kultury, Sitz im Leben.

\subsection{RELIGIA JEST NIEMORALNA}

Zdaniem nowych ateistów słynne zdanie Dostojewskiego: „jeśli Boga nie ma, to wszystko wolno", podkreślające intuicyjnie już wyczuwane

26 Por. A. McGrath, Los ateísmos de superventas: el nuevo cientificismo, "Concilium" 337 (2010), s. 556.

${ }^{27}$ Por. Ch. Hitchens, Bóg nie jest wielki, s. 102: „Bóg Starego Testamentu to chyba jeden z najmniej sympatycznych bohaterów literackich: zawistny (i dumny z tego), małostkowy i niesprawiedliwy typ, z manią na punkcie kontrolowania innych i niezdolny do wybaczania, mściwy i żądny krwi zwolennik czystek etnicznych, mizogin, homofob i rasista, dzieciobójca o skłonnościach ludobójczych". 
w kulturze powiązanie między religią i moralnościa, nie wytrzymuje krytyki w świetle aktualnej sytuacji na świecie. Zdaniem Onfraya religia i wiara $\mathrm{w}$ istnienie Boga nie uczyniła ludzi w żadnym razie lepszymi ${ }^{28}$. Widoczne to jest również $\mathrm{w}$ przestrzeni życia społecznego, gdzie zdaniem neoateistów nie ma dużej różnicy między wierzącymi a niewierzącymi, a nawet zasługi dla rozwoju cywilizacyjnego pochodzą od ludzi dystansujacych się od religii. Wynika to z faktu, jak podkreśla Comte-Sponville, że ateizm nie oznacza odrzucenia wartości, bo one nie potrzebują Boga, aby obowiązywały wszystkich ludzi. Wiara w Boga lub jej brak nie zmienia niczego w wielkich kwestiach moralnych. Wartości istnieją autonomicznie poza Bogiem. Ale jaka jest ich geneza? Odpowiedź, jakiej udzielają, świadczy o naturalistycznym podłożu. W opinii neoateistów człowiek jest istotą moralną, ponieważ to sprawiły ewolucja i geny. Dlatego - tytułem przykładu - postępowanie cnotliwe stało się imperatywem moralnym ze względu na to, że wzmacnia szanse na przeżycie. Moralność wyjaśniana z pozycji naturalistycznych jawi się jako owoc pragnienia genów, aby być nieśmiertelnymi.

Niemniej jednak odniesienie do biologii, aby wyjaśnić moralność, natrafia na wiele zastrzeżeń: skąd pochodzi „treść” moralności? Jak ślepa ewolucja może wyjaśnić, że miłość staje się cnotą? Nie udzielają odpowiedzi na pytanie o źródło moralności ${ }^{29}$. A z jakich pozycji aksojologicznych oceniają religię? Na jakiej podstawie twierdzą, że Bóg nie jest „dobry”? Trzeba mieć tu kryteria absolutne, ale jeśli nie ma Boga, to jakie kryterium może być traktowane jako "absolutne"? Programowym zadaniem jest próba "odczarowania świata”, posługując się słynnym wyrażeniem Maxa Webera i wykorzystanym potem przez Dennetta ${ }^{30}$, choć zapewne wiele jest prób jego ponownego zaczarowania, które możemy dostrzec $\mathrm{w}$ ich spojrzeniu na religię. W konsekwencji takiej wizji religia jest nie tylko amoralna, lecz głęboko niemoralna, ponieważ nakazuje nam przestać być racjonalnymi. Wiara powoduje nawet cierpienie ludzkie - zabrania badania na komórkach macierzystych, przez co cierpią ludzie.

\subsection{NATURALISTYCZNE KORZENIE RELIGII}

Konsekwencją naturalistycznego postrzegania religii (zakładającego nieistnienie Boga) jest przekonanie, iż jest ona wyłącznym dziełem

${ }^{28}$ M. Onfray, Traktat ateologiczny, s. 63.

29 E. McMullin, Ewolucja i stworzenie, Kraków 1993, s. 42-53.

${ }^{30}$ D. Dennett, Odczarowanie, Warszawa 2008. 
człowieka. Rodzi się z lęku przed śmiercią, z poczucia winy. W prezentowanych poglądach nowego ateizmu wyczuwalne jest echo twierdzeń S. Freuda, do którego wprost nawiązuje przede wszystkim M. Onfray: utrzymuje on, że religia jest przejawem "patologii osobistej”, wyraźną perwersją, neurozą i psychozą. W sposób bardziej wyrafinowany formułuje swoje poglądy Comte-Sponville upatrujący przyczyn powstania religii w lęku przed ostateczną utratą osób kochanych: to strach przed nicością rzuca człowieka w objęcia religii. Natomiast dla Dawkinsa geneza religii związana jest przede wszystkim z ewolucją: to ludzki rozum rozwinął $\mathrm{w}$ procesie ewolucji tendencję do wierzenia $\mathrm{w}$ prawdy nie oparte na dowodach. Religia okazała się przydatna dla przetrwania człowieka w cyklu ewolucyjnym. Dlatego Dawkins nie waha się określić jej jako swoisty „wirus" systemów poznawczych człowieka. To właśnie „memy”, jak już wspominaliśmy oryginalny neologizm Dawkinsa, są odpowiedzialne za przekazywanie tego wirusa z jednego organizmu człowieka do drugiego. Wiara rodzi się w człowieku w sposób nierefleksyjny: pokusa religijności jest skutkiem zainfekowania człowieka potężnym memem. Dawkins sytuuje się w linii Thomasa Huxleya, który interpretował ewolucję w duchu ateistycznym i ze względu na swą bezkompromisowość był nazywany „buldogiem Darwina” (Dawkins często jest określany jako „rotweiler Darwina"). Ateizm, zdaniem Dawkinsa, zawiera się wprost w teorii ewolucji. Odrzuca wszelki inny obraz niż naukowy, dlatego chodzi jednak nie tylko o istnienie czy nieistnienie Boga, ale mnie samego jako wolnej jednostki

Trzeba przyznać, że wyjaśnienia nowych ateistów dotyczące religii jako owocu ewolucji są najsłabszym punktem ich twierdzeń, bo niewyjaśniającym wielu fenomenów religijnych (dokonują nieuprawnionej redukcji antropologicznej), nie mówiąc już o kwestionowanej przez wielu naukowców teorii memów Dawkinsa.

\section{5 .ATEIZM JEST „PRAWIE PEWNY”}

Relacja wiary i nauki, ujmowana w kategoriach wykluczających się opcji, prowadzi do odrzucenia hipotezy Boga, która zdaniem nowych ateistów jest możliwa do odrzucenia z pozycji naukowych ${ }^{31}$. Idąc tym tropem, dokonują oni najpierw ujęcia Boga jako „hipotezy” naukowej.

${ }^{31}$ Zdecydowanie krytykują twierdzenia Stefana Gouda, który propagował postrzeganie relacji nauki i wiary jako NOMA (Non overlapping Magisteria). 
Nie jest on potrzebny do wyjaśnienia świata, dlatego - przywołując bezkrytycznie zasadę „brzytwy Ockhama”, aby nie mnożyć niepotrzebnych bytów - uważają, że świat nie potrzebuje do swej pełni wyjaśnienia istnienia inteligentnego stworzyciela ${ }^{32}$. Inny razem opierają odrzucenie hipotezy Boga na kalkulacji probabilistycznej, ale nie możemy stracić z pola widzenia, że ten rachunek prawdopodobieństwa nie dotyczy Boga, a jedynie naszych argumentów. Nie udaje się im odrzucić Boga, bo nauka się tym nie zajmuje... nie pozwala jej na to jej sama metoda. Bóg nie jest kolejnym przedmiotem świata, lecz obecnością osobową, które nadaje sens ludzkiemu życiu ${ }^{33}$.

Nowi ateiści w sposób pobieżny podchodzą do argumentów, które w toku dziejów były przedstawiane jako „drogi" prowadzące do afirmacji istnienia Boga. Argument św. Anzelma, który przeszedł do historii jako "ontologiczny" (przy kontrowersjach wokół tego określenia) uważają bardziej za "sztuczkę logiczną". Dawkins uważa, nie poświęcając przy tym zbyt wiele uwagi na dokładne analizy, że quinquae viae św. Tomasza z Akwinu są "głupie", ponieważ zakładaja, że poszukiwanie przyczyn może cofać się $\mathrm{w}$ nieskończoność, a Bóg temu nie podlega. Błędnie też utożsamia Dawkins V drogę św. Tomasza z teorią tzw. projektu inteligentnego, który de facto powstał jako odpowiedź na twierdzenia Ślepego zegarmistrza Dawkinsa. Tym samym wraca pytanie: kto stworzył Boga? Przyczyną takiego traktowania tradycyjnych argumentów na rzecz istnienia Boga jest niezrozumienie tego, co myśl filozoficzna mówi o Bogu, gdy określa go jako Ipsum Esse Subsistens. Nie jest taki jak przyczyny naturalne, lecz należy do innego porządku: ma w sobie samym rację swego istnienia. Zapominają nowi ateiści, że Bóg nie jest mieszkańcem naszego świata i nie rywalizuje z przyczynami naturalnymi w świecie. Szczególnie słabo rozumieją neoateiści tę zależność między pierwszą przyczyną a drugorzędnymi, tak niezbędną choćby dla właściwego uchwycenia myśli Akwinaty. Próbując obalić istnienie „inteligentnego projektanta”, nowi ateiści nie uzyskują potwierdzenia swego twierdzenia o nieistnieniu projektanta, lecz to, że nie działa on bezpośrednio. Tłumacząc wszystko

32 Por. S. Wszołek, W obronie argumentu God of the gaps, ZFwN 23 (1998), s. 103; C. Berg, Leaving Behind the God-of-the-Gaps: Towards a Theological Response to Scientific Limit Questions, w: R. Hermann (red.), Expanding Humanity's Vision of God, Templeton Foundation Press, Philadelphia 2001, s. 89-92.

${ }^{33}$ Por. G. Timossi, L'illusione dell'ateismo. Perché la scienza non nega Dio, San Paolo, Cinisello Balsamo 2009, s. 55. 
selekcją naturalną, mogą wyjaśniać jedynie ,jak" (dla nowych ateistów to będzie "cios szczęścia”, przypadek), ale nie "dlaczego" 34 .

Gdy przechodzą do analizy natury Boga, w zdecydowany sposób opowiadają się przeciwko tezie o prostocie Boga, jak bowiem - ich zdaniem - może byt niezłożony być przyczyną takich złożeń, jakie występują w świecie. Bóg musiałby być swoistym „superkomputerem”. Nie jest to własne twierdzenie, ale odwołujące się już do Hume i dokonujące jego postmodernistycznej mutacji. Neoateiści ponownie zapominają jednak, że Bóg jest bytem transcendentnym, który nie należy do świata cielesnego. Uwięzieni w swoich własnych kategoriach, traktując je w sposób absolutny, na własną miarę kształtują swoją, głęboko antropomorficzną wizję Boga: to wizja "szyta” na miarę człowieka. Widać to wyraźnie przy okazji krytyki wszechmocy Boga, która neguje ludzką wolność. Nie mogą oni uwolnić się od myślenia o Bogu w siatce czasu i dotyczy to również pytania o istnienie zła na świecie i odpowiedzialność Boga za ten stan rzeczy.

\subsection{GNOSTYCYZM I NEGACJA HISTORYCZNOŚCl EWANGELIl}

Już w przedstawionych powyżej argumentach nowego ateizmu ujawnia się zdecydowanie gnostycki charakter tego ruchu: oddzielanie wiary od historii i jakiejkolwiek możliwości objawienia nadprzyrodzonego. Wynika ona, zdaniem neoateistów, już z samego faktu wielości religii istniejących na świecie, co sprawia, że nie ma obiektywnych kryteriów, aby zdecydować, która z nich jest prawdziwa. Relatywizm nowych ateistów bazuje na przekonaniu, że religia jest produktem kultury, który przyjmuje się ze względu na polityczną rachubę. Zaprzeczeniem Objawienia jest także sam fakt istnienia wielu świętych tekstów, które już w ramach synchronicznej analizy ich treści ujawniają szereg sprzecznych passusów. Jak już wspominaliśmy, wynika to z fundamentalistycznej lektury Pisma Świętego, która nie uwzględnia rodzajów literackich, a opiera się na rozumieniu natchnienia biblijnego jako dyktatu Boga. Wedle tych poglądów autorzy biblijni byliby po prostu stenotypistami Boga. Harris

${ }^{34} \mathrm{~W}$ znamienny sposób włącza się w dyskusję nad sensownością twierdzenia, że świat jest dziełem „przypadku” M. Heller w swej książce Filozofia przypadku (Znak, Kraków 2013), dedykując ją Dawkinsowi i zwolennikom teorii inteligentnego projektu. W dyskusji dostrzega wiele nieporozumień, które nie prowadzą do rozwiązań. 
uważa, że jeśli Biblia rzeczywiście byłaby dziełem Boga, nie zawierałaby błędów matematycznych i mówiła o elektryczności czy DNA, a zwłaszcza o tym, jak wyleczyć raka. Właściwie każde zdanie Biblii mogłoby zostać napisane przez jakiegokolwiek człowieka, co samo przez się jest dowodem na to, że nie mamy do czynienia z żadną interwencją boską.

Zadziwiające jest jednak to, że niektórzy z nich - jak Dawkins wysuwają wątpliwości nawet co do historycznego istnienia Jezusa Chrystusa. Czyni to w subtelny sposób, pokazując jedynie, że jest możliwe wyobrażenie sobie przypadku, w którym mogłoby dojść do fikcyjnego montażu postaci takiej jak Jezus. Wtóruje mu Onfray, który żąda weryfikacji naukowej istnienia Jezusa na podstawie dokumentów epoki czy dowodów archeologicznych, mogących świadczyć o tym, że był kimś, kto pośredniczył między dwoma światami. Jeszcze dalej idzie Hitchens, który stwierdza, że istnienie Jezusa jest „bardzo wątpliwe”. Wszyscy nowi ateiści zgodnie odrzucają historyczność Ewangelii, ponieważ nie opierają się na rzetelnych badaniach nad osobą Jezusa. Ewangeliści prawie na pewno Go nie znali, a dzieła, które napisali to wytwór propagandy (Onfray). Sam wybór kanonu to, ich zdaniem, rezultat arbitralnej decyzji ludzkiej. Tym samym powtarzają za Nietzschem jego przekonanie, że chrześcijaństwo wymyślił św. Paweł. Znamienne jest jednak to, że proponując tak śmiałe wyroki na historyczność ewangelii, nie podają żadnych dowodów, nie biorą pod uwagę procesu kształtowania kanonu i zgodności pierwotnego Kościoła co do tego faktu. Negując historyczność Jezusa, narażają się na zarzut ignorancji wśród historyków.

\subsection{PROMOCJA „LAICYZMU WYKLUCZAJĄCEGO"}

Wszystkie wspomniane wyżej argumenty prowadzą do przyjęcia pewnych praktycznych postaw przez nowych ateistów. U ich źródła stoi odrzucenie obowiązującej do tej pory oświeceniowej zasady tolerancji dla religii. Powinno się odstąpić od automatycznego szacunku dla religii, gdyż jej konsekwencją jest perwersja umysłu, której dokonuje wiara. Religie były zbyt mocno szanowane w zachodniej kulturze, mają swoje niezasłużone przywileje, które powinny zostać jej odebrane. Postulują radykalne kroki: zamiast pozwalać na nauczanie religii w szkołach, powinno się prowadzić nauczanie ateizmu.

Oczekują oni epoki otwarcie ateistycznej i dlatego w tej zmianie strategii na pierwszy plan wysuwa się promowanie dumy $\mathrm{z}$ bycia ateista, 
ukazywanie, że gdzie pojawia się ateizm, tam jest mniej przemocy, dominuje niezależność umysłowa, zdrowa inteligencja. Celem neoateistów jest zbudowanie kontynentu postchrześcijańskiego, co nastąpi dopiero wówczas, gdy dokonana zostanie dechrystianizacja metafizyki i moralności. Stawiają więc nie tyle na naukowy dialog dotyczący istnienia Boga, co pragną usprawiedliwić politykę poszczególnych państw. Przyglądając się postulatom nowego ateizmu można zauważyć, że ateizm nie jest czystym brakiem wierzeń, ale filozofią życia, która może wzniecać silne emocje i również - jak pokazuje historia - być źródłem przemocy (rewolucja francuska).

\section{DROGI DIALOGU: CO OZNACZA NOWY ATEIZM DLA TEOLOGII CHRZEŚCIJAŃSKIEJ}

Po przedstawieniu zasadniczych punktów programu nowego ateizmu warto zastanowić się nad możliwością dialogu z chrześcijańską teologią, choć druga strona - neoateizm - zbytnio na dialog nie stawia (i to nie tylko ze względu na swoją retorykę). Kluczowe dla ustalenia ram dyskursu powinno być pytanie o renesans kwestii Boga w naszych czasach i dlaczego poglądy nowych ateistów natrafily na podatny grunt. Być może przyczną takiego stanu rzeczy jest nierozwiązanie pewnych trudnych problemów, zarówno praktycznych, jak i teologicznych. W ten sposób pojawia się okazja do przemyślenia najważniejszych topik współczesności, w których głos teologii - zwłaszcza teologii fundamentalnej - jest niezwykle cenny ${ }^{35}$.

\subsection{TROSKA O WŁAŚCIWY OBRAZ BOGA}

Na kartach dzieł „nowego ateizmu” może przerażać człowieka wiary i znającego dziedzictwo filozoficzno-teologiczne chrześcijaństwa sposób, w jaki przedstawia się w nich Boga i wyznawcę Chrystusa. Niemniej jednak każdy ateizm, wczoraj i dziś, jest wezwaniem do czujności i oczyszczania obrazu Boga, który w sposób naturalny doświadcza w nas pokusy antropomorfizacji. Nie jest przypadkiem, że największe syntezy

${ }_{35}$ Por. J. Alonso, Ateismo e increencia segun el Concilio Vaticano II, "Scripta Theologica" 2 (2013), s. 395-423. 
teologiczne - Akwinata jest tego dobrym przykładem - rozpoczynały dyskurs o Bogu od refleksji nad naturą języka teologicznego: $w$ jaki sposób orzekamy o Bogu? Czy nasz język jest w stanie objąć i wyrazić tajemnicę transcendentnego Boga?

Optymizm bazujący na fakcie Objawienia nie może przysłonić paradoksalnego charakteru tego języka, który z pokorą musi uznać swoje ograniczenia. Droga wiary to ciągły wysiłek oczyszczania obrazu Boga, odrzucania iluzji i łatwych klasyfikacji, które ignorują to, że Bóg pozostaje „świetlistą ciemnością", wedle słynnego wyrażenia Pascala. Bóg jest i pozostanie tajemnicą.

Nowy ateizm oznacza w konsekwencji ważne wyzwanie hermeneutyczne do odczytywania "trudnych" kart Pisma Świętego. Odczytanie przez neoateistów pewnych wydarzeń opisywanych w Starym Testamencie domaga się pogłębionej uwagi egzegezy chrześcijańskiej i wypracowania integralnej odpowiedzi, która z pozycji teologicznych wyjaśni kwestie objawienia w Starym Testamencie.

\section{2. „WIDZIALNOŚĆ" RELIGII W ŻYCIU SPOŁECZNYM}

Jeden z przedstawicieli radykalnej ortodoksji, Graham Ward, wskazywał na konieczność refleksji nad „nową widzialnością” religii w obecnym układzie kulturowym. W obliczu propagowanego laicyzmu wykluczającego refleksja teologiczna winna iść w kierunku wskazanym przez Benedykta XVI, który podczas swej wizyty w Bundestagu proponował ideę "laicyzmu pozytywnego". To takie ułożenie relacji społecznych, w których jest miejsce dla religii, będącej dobrodziejstwem społecznym. Istotne znaczenie będą miały studia poświęcone fenomenowi religii, zarówno w perspektywie historyczno-systematycznej, jak egzystencjalnej, na miarę problemów generowanych przez globalizację. Nowi ateiści patrzą na religię w sposób zewnętrzny, pomijając jej najistotniejsze elementy ${ }^{36}$.

${ }^{36} \mathrm{~W}$ ten sposób są też ostrzeżeniem przed możliwym „bezistociem religii” (B. Welte), skupieniem tylko na tym, co zewnętrzne, bez odniesienia do "środka", który nadaje sens i tożsamość - por. R. Woźniak, Zapomniane chrześcijaństwo: o zadaniu teologii fundamentalnej w kontekście „wieku świeckiego", w: P. Roszak (red.), U zródet pamięci. O zapomnieniu w historii, teologii i literaturze, Torun 2013, s. 39-53. 


\subsection{RACJONALNOŚĆ „POSZERZONA"}

Nowy ateizm to wezwanie dla teologii fundamentalnej, aby na nowo odkrywać naturę wiary. Cenną inicjatywą w tym względzie był przeżywany Rok Wiary, który zainicjował szereg refleksji nad aktem wiary, jego racjonalnością i odrzucaniem nakładek, które wypaczają sens wiary. Wbrew temu, co twierdzą nowi ateiści, wiara nie jest ślepa, lecz istnieją pewne racje, aby wierzyć - choć nie wierzymy z powodu racjii ${ }^{37}$. Chodzi w ten sposób o budowanie kultury wiary, która świadoma swego statusu epistemologiczno-egzystencjalnego, nie jest „wiedzą", ale też zwykłą „opinią”, która będzie otwierała wierzących na znaczenie rozumu. Myślenie wiary i wiara myśląca to dobra odpowiedź na zastrzeżenia neoateistów i zagrożenia sekularyzmu: nie można bowiem zamknąć się $\mathrm{w}$ subiektywności, ale próbować wyrażać uniwersalną propozycję chrześcijaństwa ${ }^{38}$.

Nowy ateizm cechuje się materializmem scjentystycznym, który pojawia się jednak nie tyle automatycznie jako konsekwencja postawy naukowej, ile jest postawą filozoficzną: owocem konkretnych rozwiązań metafizycznych. Programowa empiryczność ograniczająca się jedynie do tego, co materialne, jest tezą metaficzną, która powinna zostać powierdzona doświadczeniem. Nie ma wyjaśnienia, czym jest racjonalność empiryczna, czy empiryczne nie jest doświadczenie samego siebie, swego wnętrza, miłości osobowej? W dyskusji z neoateizmem ważne byłoby uświadomienie sobie filozoficznych pozycji, z których wynika przyjmowany przez nich redukcjonizm epistemologiczny ${ }^{39}$. Oznacza to podjęcie rozważań nad koncepcją racjonalności, która dominuje współcześnie i doświadcza wielu redukcyjnych transformacji ${ }^{40}$. Tymczasem wyzwaniem jest poszerzenie racjonalności, która by była w pełni sobą, powinna wyswobodzić się z uproszczeń i redukcjonizmów ograniczających jej horyzonty ${ }^{41}$.

37 Por. P. Roszak, Wiarygodnosć i tożsamość, s. 115.

${ }^{38}$ G. Sgubbi, Il "Nuovo Ateismo", la fede e la teologia, "Rivista Teologica di Lugano" 3 (2010), s. 439-478.

39 P. Candler, 'God is Dead' and I Don't Feel So Good Myself, w: A. David, Ch. Keller, J. Stanley (red.), 'God is Dead' and I Don't Feel So Good Myself: Theological Engagements with the New Atheism, Eugene 2010, s. 80-94.

${ }^{40} \mathrm{Y}$. Labbé, La rationalité de la révélation, „Revue théologique de Louvain” 41 (2010), s. 32-56.

${ }^{41}$ J. Szymik, Wspótczesne zadania teologii. Wizja J. Ratzingera/Benedykta XVI, „Teologia w Polsce” 1 (2010), s. 49-63. 


\subsection{NOWE KANAŁY DIALOGU MIĘDZY NAUKĄ - KULTURĄ - WIARĄ}

Nowy ateizm prowokuje teologię do ciągłego wysiłku przedstawienia Boga w języku, który okaże się przekonujący dla współczesnego człowieka, uwzględniający jego kontekst kulturowy, naznaczony również odkryciami naukowymi ${ }^{42}$. Kluczowe jest to, aby konieczny dialog między nauką a wiarą nie pozostawał w ręku fundamentalizmów, zarówno naukowego, jak i religijnego ${ }^{43}$. Istotne staje się tworzenie, postulowane przez Benedykta XVI, kanałów dialogu, w którym niezbędnym warunkiem jest uznanie autonomii nauki, ale również specyficznego charakteru wiedzy i wiary. W tym kierunku rozwija się inicjatywa "przedsionków pogan”, które mają stać się przestrzenią dialogu.

\subsection{ATRAKCYJNOŚĆ CHRZEŚCIJAŃSKIEJ NARRACJI}

Każda twórcza dyskusja przynosi z sobą konieczność zwrócenia bacznej uwagi na szczegóły, precyzyjną terminologię i rozróżnienia, aby nie stawiać znaku równości między zjawiskami, które tylko przy pobieżnym spojrzeniu wydają się tożsame. W przypadku nowych ateistów widać wyraźnie, że nie odróżniają od siebie teizmu i kreacjonizmu. To „wyostrzeżenie" uwagi jest kluczowe dla owocnego dialogu.

W dyskusji z nowym ateizmem może wybrzmieć nieprzemijająca atrakcyjność chrześcijańskiej narracji, która ma do przekazania zdecydowanie ciekawszą opowieść o człowieku i Bogu, prawdziwą i pogłębioną niż proponuje to nihilizm czy ateizm, operujące wieloma redukcjonizmami. Neoateizm to szansa na przypomnienie ważnych egzystencjałów „W czasach trudnych" dla człowieka, by posłużyć się tytułem książki M. Szulakiewicza ${ }^{44}$, wśród których powraca ze szczególną siłą przekonanie o otwarciu się człowieka na transcendencję. Ateizm próbuje zaspokoić

42 Jak to już nieraz bywało $\mathrm{w}$ historii teologii, znamienny pod tym względem jest przypadek średniowiecza - por. D. Toma, A Dionysian/Thomistic Framework for the Integration of Science and Catholic Tradition, "Logos” 3 (2013), s. 87-113.

${ }^{43}$ J. Polkinhgorne, Nauka i stworzenie. Poszukiwanie zrozumienia, tłum. M. Chojnacki, Kraków 2008, s. 21-45.

${ }^{44}$ M. Szulakiewicz, O człowieku w czasach trudnych. Urywki filozoficzne, Toruń 2012. 
"głód" w sposób niewystarczający, pochopny, ale tym samym odsłania, że człowiek ciągle potrzebuje "czegoś więcej”, Kogoś więcej, gdyż jest capax Dei.

Streszczenie. Celem artykułu jest „mapowanie” neoateizmu oraz przedstawienie jego głównych argumentów. Wynikiem tego jest opis dwóch głównych tendencji "nowego ateizmu” (naukowego i kontynentalnego) oraz ich relacji do religii charakteryzującej się pozycją naturalistyczną. „Nowy ateizm” szeroko analizuje argumenty przeciw religii (traktując ją jako niemoralną, źródło przemocy oraz rezultat uwarunkowań biologicznych).

Systematyczny rozwój "nowego ateizmu” miesza także „stare" i „nowe” tezy, oznaczając powrót do tradycyjnych argumentów antyteistycznych, ale przekazywanych w nowej perspektywie.

Druga część artykułu zawiera wskazania potencjalnych zagadnień dialogu $\mathrm{z}$ „nowym ateizmem" oraz otwarte wyzwania dla współczesnej teologii: troska o właściwy obraz Boga, „widzialność” religii w życiu społeecznym, poszerzona wizja racjonalności oraz atrakcyjność chrześcijańskiej narracji.

Słowa klucze: nowy ateizm, racjonalność, apologetyka, wiara i rozum

Abstract. New Atheism: is really "new"? Analysis of the arguments and challenges for contemporary theology. The article intents a "mapping" of New Atheism and presents its main arguments. The result is a characterization of two major trends of new atheism (scientific and continental), and their relation to religion, which is characterized by naturalistic approach. New atheism largely examines the arguments against religion (treating it as immoral, a source of violence and as the effects of biological conditions). The systematic development of the new atheism also mixed the "old" and "new" means in fact a return to the traditional arguments antitheistic, but presented in a new perspective. The second part of the article includes indication of the possible topics of dialogue with the new atheism and the challenges that will be opened for contemporary theology: care of God's image among believer, visibility of religion in society, broad vision of rationality and the attractiveness of the Christian narrative.

Keywords: new atheism, rationality, apologetics, faith and reason 